A Reassessment of the Relationship between Inequality and Growth

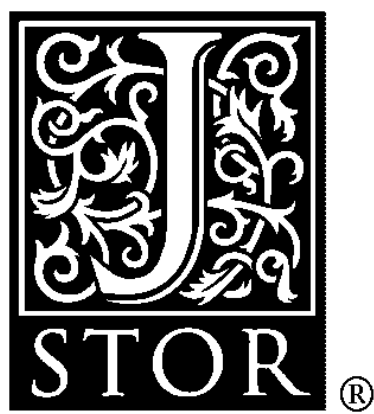
Author(s): Kristin J. Forbes

Source: The American Economic Review, Vol. 90, No. 4, (Sep., 2000), pp. 869-887

Published by: American Economic Association

Stable URL: http://www.jstor.org/stable/117312

Accessed: 23/05/2008 01:11

Your use of the JSTOR archive indicates your acceptance of JSTOR's Terms and Conditions of Use, available at http://www.jstor.org/page/info/about/policies/terms.jsp. JSTOR's Terms and Conditions of Use provides, in part, that unless you have obtained prior permission, you may not download an entire issue of a journal or multiple copies of articles, and you may use content in the JSTOR archive only for your personal, non-commercial use.

Please contact the publisher regarding any further use of this work. Publisher contact information may be obtained at http://www.jstor.org/action/showPublisher?publisherCode=aea.

Each copy of any part of a JSTOR transmission must contain the same copyright notice that appears on the screen or printed page of such transmission.

JSTOR is a not-for-profit organization founded in 1995 to build trusted digital archives for scholarship. We enable the scholarly community to preserve their work and the materials they rely upon, and to build a common research platform that promotes the discovery and use of these resources. For more information about JSTOR, please contact support@jstor.org. 


\title{
A Reassessment of the Relationship Between Inequality and Growth
}

\author{
By KRISTIN J. FORBES*
}

\begin{abstract}
This paper challenges the current belief that income inequality has a negative relationship with economic growth. It uses an improved data set on income inequality which not only reduces measurement error, but also allows estimation via a panel technique. Panel estimation makes it possible to control for time-invariant country-specific effects, therefore eliminating a potential source of omitted-variable bias. Results suggest that in the short and medium term, an increase in a country's level of income inequality has a significant positive relationship with subsequent economic growth. This relationship is highly robust across samples, variable definitions, and model specifications. (JEL O40, O15, E25)
\end{abstract}

In the 1950's and 1960's, economists such as Nicholas Kaldor and Simon Kuznets argued that there is a trade-off between reducing inequality and promoting growth. In the postWorld War period, however, many East Asian economies had relatively low levels of inequality (for countries of comparable income levels) and grew at unprecedented rates. In sharp contrast to this experience, many Latin American countries had significantly higher levels of inequality and grew at a fraction of the average East Asian rate. These trends prompted a surge of interest in the relationship between inequality and growth, and in particular, a reassessment of how a country's level of income inequality predicts its subsequent rate of economic growth.

Over the past five years, many economists have attempted to measure this relationship by adding inequality as an independent variable to some variant of Robert J. Barro's cross-country growth regression. ${ }^{1}$ These studies generally find a nega-

* Sloan School of Management, Room E52-446, Massachusetts Institute of Technology, 50 Memorial Drive, Cambridge, MA 02142. Thanks to Daron Acemoglu, Abhijit Banerjee, Andrew Bernard, Rudiger Dornbusch, Oded Galor, Robert Solow, Jaume Ventura, and the anonymous referees at the AER for extremely helpful comments and criticism. Special thanks to Norman Loayza for an insightful discussion on panel estimation.

${ }^{1}$ For examples of this regression, see Barro and Xavier Sala-i-Martin (1995). For examples of inequality added to this framework, see Alberto Alesina and Roberto Perotti (1994), Alesina and Dani Rodrik (1994), Torsten Persson and Guido Tabellini (1994), Nancy Birdsall et al. (1995), tive and just-significant coefficient on inequality, leading most economists to conclude that inequality has a negative impact on growth. This line of research has received such widespread support that a recent survey of this work concludes: "These regressions, run over a variety of data sets and periods with many different measures of income distribution, deliver a consistent message: initial inequality is detrimental to long-run growth" (Roland Benabou, 1996b p. 13). This message has been so widely accepted that it has recently motivated a series of papers explaining the specific channels through which inequality might affect economic growth. ${ }^{2}$

Although most of these papers focus on theories establishing a negative effect of inequality on growth, a careful reading of this literature suggests that this negative relationship is far less definitive than generally believed. In many models, the negative relationship depends on exogenous factors, such as aggregate wealth, political institutions, or the level of development. Many of these papers predict multiple equilibria, so that under certain initial conditions, inequality could have a positive relationship with economic growth. Moreover, several recent papers have developed models that predict a positive relationship between inequality

\footnotetext{
George R. Clarke (1995), and Klaus Deininger and Lyn Squire (1998).

${ }^{2}$ See Benabou (1996b) and Perotti (1996) for excellent surveys of this empirical and theoretical work.
} 
and growth. For example, Gilles Saint-Paul and Thierry Verdier (1993) argue that in more unequal societies, the median voter will elect a higher rate of taxation to finance public education, which will increase aggregate human capital and economic growth. Benabou (1996a) develops a model based on heterogeneous individuals and shows that if the degree of complementarity between individuals' human capital is stronger in local than global interactions, then segregated and more unequal societies can experience higher rates of growth (at least in the short run). Oded Galor and Daniel Tsiddon (1997a, b) develop two theories of why inequality and growth could be positively related. In one model, a home environment externality helps determine an individual's level of human capital, and if this externality is strong enough, a high level of inequality may be necessary for growth to "take off" in a less-developed economy. In a second model, Galor and Tsiddon argue that inequality increases during periods of major technological inventions, which, by enhancing mobility and the concentration of high-ability workers in technologically advanced sectors, will generate higher rates of technological progress and growth.

These theoretical papers predicting a positive relationship between inequality and growth have received less attention in this branch of literature because all recent empirical work has reported a negative relationship between these variables. There are, however, a number of potential problems with this empirical work. First, many of the estimates of a significant negative effect of inequality on growth are not robust. When any sort of sensitivity analysis is performed, such as when additional explanatory variables or regional dummy variables are included, the coefficient on inequality often becomes insignificant (although it usually remains negative). Deininger and Squire (1998 p. 269) emphasize this point, which leads them "to question the robustness and validity of the negative association between inequality and growth."

Second, all of these studies have two potential econometric problems: measurement error in inequality and omitted-variable bias. ${ }^{3}$ Ran-

\footnotetext{
${ }^{3}$ Deininger and Squire (1998) is the one study that addresses the problem of measurement error by using the new data set described below. Deininger and Squire, how-
}

dom measurement error could generate an attenuation bias and reduce the significance of results. Potentially more problematic, however, systematic measurement error could lead to either a positive or negative bias, depending on the correlation between the measurement error and the other variables in the regression. For example, if more unequal countries tend to underreport their inequality statistics and also tend to grow more slowly than comparable countries with lower levels of inequality, this could generate a negative bias in cross-country estimates of the impact of inequality on growth.

Omitted-variable bias could be equally problematic, although it is impossible to predict the direction of this bias in a multivariate context. If there are strong univariate correlations between an omitted variable, inequality, and growth, however, these relationships could outweigh any multivariate effects and generate a significant, predictable bias. For example, if a country's degree of capitalism, support for entrepreneurship, and/or amount of labor-market flexibility is omitted from the growth equation (and each of these variables tends to be positively correlated with both inequality and growth), this could generate a positive bias on estimated inequality coefficients. On the other hand, if the level of corruption (which tends to be positively correlated with inequality and negatively correlated with growth) is omitted from the growth equation, this could generate a negative bias on the estimated inequality coefficient. Given the numerous variables that are difficult to measure and include in a growth regression, it is difficult to predict a priori how omitted variables could affect estimates of the relationship between inequality and growth.

A third issue with this cross-country work on inequality and growth is that it does not directly address the important policy question of how a change in a country's level of inequality will affect growth within that country. The cross-country regression results show the long-term pattern that countries with lower levels of inequality have tended to grow more quickly. This has been interpreted to imply that governments which

ever, do not address the potential problem of omittedvariable bias. 
undertake policies to reduce inequality could simultaneously improve long-term growth performance. Although the cross-country results support this interpretation, they do not directly address this issue of how a change in inequality within a given country is related to growth within that country. The direct method for estimating this relationship is to utilize panel estimation. Panel techniques can specifically estimate how a change in a country's level of inequality predicts a change in that country's growth rate.

This paper addresses each of these three issues and reassesses the relationship between inequality and growth. Section I discusses previous empirical work on this topic and suggests using more consistent data to control for any measurement error and panel estimation to control for any timeinvariant omitted variables. Section II describes the data set and model to be utilized and Section III estimates this model, using a generalized method of moments technique developed by Manuel Arellano and Stephen R. Bond (1991). Results suggest that in the short and medium term, an increase in a country's level of income inequality has a strong positive correlation with subsequent economic growth.

Since this significant positive relationship is in sharp contrast to the negative relationship reported in the cross-country literature, Section IV investigates why results differ. It finds that data quality, period length, and estimation technique all influence the sign and significance of the coefficient on inequality. Section $\mathrm{V}$ conducts a detailed sensitivity analysis of this paper's central results, confirming that this positive relationship is highly robust to many permutations of the original sample and model. The one caveat is that these results may not apply to very poor countries, since inequality data for these nations are still limited. Section VI concludes with a number of caveats to these results and emphasizes that these estimates of a shortrun positive relationship between inequality and growth within a given country do not directly contradict the previously reported long-run negative relationship across countries. Instead, these results should be taken as a complement to existing studies, not only raising doubts about their "consistent message," but also suggesting that further careful reassessment of the numerous linkages between inequality, growth, and their determinants is necessary.

\section{Improved Inequality Statistics and Panel Estimation}

Previous work measuring how inequality is related to economic growth was limited by the availability of cross-country statistics measuring inequality. Data availability created the potential not only for measurement error, but also for omitted-variable bias (since the data did not have a large enough time-series dimension to use panel estimation). This section explains how an improved set of inequality statistics should not only reduce measurement error, but also allow panel estimation of the relationship between inequality and growth.

Measurement error is always a concern in cross-country studies. Countries have different definitions of key variables and varying degrees of accuracy in data collection. One of the variables subject to the most severe measurement error is inequality. ${ }^{4}$ Few countries have compiled data on income distribution on a regular basis and much of the data which has been collected is unreliable. Coverage is generally uneven, and there is a lack of consistency in the definition of income and the unit of account. As a whole, whereas most studies acknowledge that inequality statistics are plagued with measurement error, they also admit that since no good instrument for inequality exists, it is difficult to correct for this problem.

In the past few years, however, Deininger and Squire (1996) have painstakingly compiled a far more consistent and comprehensive data set on inequality. They began by assembling as many income distribution variables as possible. Then they filtered out those observations that satisfied three minimum standards of quality. Their standards were: the data must be based on household surveys; the population covered must be representative of the entire country; and the measure of income (or expenditure) must be comprehensive, including income from selfemployment, nonwage earnings, and nonmonetary income.

Although these criteria do not appear extremely stringent, much of the data used in previous stud-

\footnotetext{
${ }^{4}$ For further discussion of problems with measures of income inequality, see Donald McGranahan (1979), Jonggoo Park and Wouter Van Ginneken (1984), Sudhir Anand and S. M. Ravi Kanbur (1993), Gary S. Fields (1994), and Deininger and Squire $(1996,1998)$.
} 
ies does not satisfy them. Deininger and Squire began with about 2,600 observations, but only 682 met the requirements to be included in their "highquality" data set. A majority of the statistics used in some of the most well-known analyses of inequality and growth did not qualify. Moreover, this new data set also has a significantly greater number of observations and covers a broader range of countries than in any previous data compilation. As a result, Deininger and Squire's new data set not only can minimize measurement error in inequality and any resulting coefficient bias, but also can increase the efficiency of estimates. In one of the first applications of this data set, Deininger and Squire (1998) use a simple crosscountry model to estimate the long-term effect of inequality on growth. They find that using the improved measures of income inequality does not change the previous result: the coefficient on inequality is negative and significant in the base regression and becomes highly insignificant when regional dummy variables are included. ${ }^{5}$

This impact of including regional dummy variables suggests a potentially even more serious limitation of previous work examining the relationship between inequality and growth: omittedvariable bias. Since the dummy variables are significant, this indicates that region-specific factors affecting growth are not captured by the explanatory variables. Moreover, since the regional variables render the coefficient on inequality insignificant, this suggests that the coefficient on inequality may actually capture the effect of these omitted variables on growth, instead of the direct influence of inequality. Any sort of omittedvariable bias can be a significant problem in a cross-country growth regression. If a variable that helps explain growth is correlated with any of the regressors and is not included in the regression, then coefficient estimates and standard errors will be biased. As discussed in the introduction, the direction of the bias is determined by the relationship between the omitted variable and the regressors and is difficult to sign a priori.

One method of reducing omitted-variable bias is to use a panel instead of the standard crosscountry data. Panel estimation controls for differ-

\footnotetext{
${ }^{5}$ Other studies that find the same result are: Alesina and Perotti (1993), Persson and Tabellini (1994), and Birdsall et al. (1995).
}

ences in time-invariant, unobservable country characteristics, thereby removing any bias resulting from the correlation of these characteristics with the explanatory variables. This technique does not adjust for all omitted-variable bias since it does not control for omitted variables whose values change over time, but papers estimating the neoclassical growth model show that using panel estimation can significantly change coefficient estimates. ${ }^{6}$ Many studies examining the relationship between inequality and growth admit that this sort of adjustment would be useful, but since panel estimation requires observations across time for each country, as well as across countries, the paucity of inequality data available has made meaningful panel estimation impossible. The new data set compiled by Deininger and Squire, however, has a time-series dimension for enough countries that panel estimation is finally viable.

To summarize, this paper uses a new data set compiled by Deininger and Squire to analyze the relationship between inequality and growth. These improved inequality statistics should not only reduce measurement error, but also allow the use of panel estimation techniques. Before performing this estimation, however, it is necessary to develop the specific model and data set to be utilized.

\section{The Model and the Data}

This paper estimates growth as a function of initial inequality, income, male and female human capital, market distortions, and country and period dummy variables - a model similar to that used in most empirical work on inequality and growth. More specifically, I chose this model since it is almost identical to that used by Perotti (1996) in his definitive study finding a negative effect of inequality on growth. The only change from Perotti's model is the addition of the dummy variables. The country dummies are included to control for time-invariant omitted-variable bias, and the period dummies are included to control for global shocks, which might affect aggregate growth in any period but are not otherwise captured by the explanatory variables.

\footnotetext{
${ }^{6}$ Some of the first papers to make this point are Malcolm D. Knight et al. (1993), Nazrul Islam (1995), and Francesco Caselli et al. (1996).
} 
It is obviously possible to include a number of additional variables; however, this paper focuses on this simplified specification for three reasons (reasons similar to why it was originally chosen by Perotti). First, this model is typical of that used to estimate the effect of inequality on growth, so any discrepancy between this paper and previous work cannot be explained by model specification. Second, since sample size is already limited by the availability of inequality statistics, and especially since panel estimation requires a large number of observations, this simple specification helps maximize the degrees of freedom. Third, and finally, by focusing on stock variables measured at the start of the periods, rather than flow variables measured throughout the periods, any endogeneity should be reduced (although it could still be a potential problem). To summarize, the growth model central to this paper is

$$
\begin{aligned}
\text { (1) } \text { Growth }_{i t}= & \beta_{1} \text { Inequality }_{i, t-1} \\
& +\beta_{2} \text { Income }_{i, t-1} \\
& +\beta_{3} \text { MaleEducation }_{i, t-1} \\
& +\beta_{4} \text { FemaleEducation }_{i, t-1} \\
& +\beta_{5} \text { PPPI }_{i, t-1}+\alpha_{i} \\
& +\eta_{t}+u_{i t},
\end{aligned}
$$

where $i$ represents each country and $t$ represents each time period (with $t=1,2 \cdots T$ ); Growth $_{i t}$ is average annual growth for country $i$ during period $t$; Inequality ${ }_{i, t-1}$, Income $_{i, t-1}$, MaleEducation Mat $-1_{i}$, FemaleEducation $_{i, t-1}$, and $P P P I_{i, t-1}$ are, respectively, inequality, income, male and female education, and market distortions for country $i$ during period $t-1 ; \alpha_{i}$ are country dummies; $\eta_{t}$ are period dummies; and $u_{i t}$ is the error term.

The data used to estimate this model come from four sources. Inequality is drawn from Deininger and Squire (1996) and Inequality is measured by the gini coefficient. Income and the resultant growth rates are taken from the World Bank STARS data set, with income measured by the log of real GNP per capita. Human capital statistics come from Barro and Jong W. Lee (1996) and are represented by average years of secondary schooling. Market distortions are drawn from the Penn World Tables and are proxied by the price level of investment. ${ }^{7} \mathrm{De}-$ tailed sources and definitions for each of these variables are listed in Table 1.

Because of data availability, this paper focuses on growth from 1966-1995. Moreover, since yearly growth rates incorporate short-run disturbances, growth is averaged over five-year periods. ${ }^{8}$ This reduces yearly serial correlation from business cycles. It is therefore possible to estimate six periods of growth for each country, and I only include countries with observations for at least two consecutive periods. Applying these criteria to the preceding data sets generates a sample of 45 countries and 180 observations. This final data set, with means, standard deviations, and ranges for each of the variables is reported in Table 1. Table 2 lists countries and their corresponding gini coefficients.

This final data set, although clearly a vast improvement over that used in past work on the effect of inequality on growth, still has several problems. First, Table 2 shows the limited number of observations available for many countries and earlier time periods. Second, regional coverage is far from representative, with no countries from sub-Saharan Africa and nearly half the sample from the OECD. Third, all of the gini coefficients are not based on identical units of account. For example, some are based on the household, whereas others are based on the individual; some are based on expenditure, whereas others are based on income. ${ }^{9}$ These shortcomings are addressed in the sensitivity analysis.

\footnotetext{
${ }^{7}$ This variable is frequently used in the macroeconomic and international literature and measures how the cost of investment varies between each country and the United States. It is meant to capture market distortions that affect the cost of investment, such as tariffs, government regulations, corruption, and the cost of foreign exchange.

${ }^{8}$ For example, this means that growth in period 3 is measured from 1976-1980 and is regressed on explanatory variables measured during period 2 (1971-1975). In practice, each explanatory variable is measured in 1975 , except inequality, which is often not available on an annual basis and is taken from the year closest to 1975 in the stated period.

${ }^{9}$ To reduce any inconsistency resulting from the fact that some gini coefficients are based on income, whereas others are based on expenditure, I follow Deininger and Squire's suggestion and add 6.6 to gini coefficients based on expenditure. See Deininger and Squire (1996) for further discussion of this adjustment and other data problems.
} 
Table 1-Summary Statistics: High-Quality Data

\begin{tabular}{|c|c|c|c|c|c|c|c|}
\hline Variable & Definition & Source & Year & Mean & $\begin{array}{l}\text { Standard } \\
\text { deviation }\end{array}$ & Minimum & Maximum \\
\hline $\begin{array}{l}\text { Female } \\
\qquad \text { Education }\end{array}$ & $\begin{array}{l}\text { Average years of secondary } \\
\text { schooling in the female } \\
\text { population aged over } 25\end{array}$ & Barro \& Lee & $\begin{array}{l}1965 \\
1970 \\
1975 \\
1980 \\
1985 \\
1990\end{array}$ & $\begin{array}{l}0.90 \\
0.95 \\
1.11 \\
1.40 \\
1.54 \\
1.76\end{array}$ & $\begin{array}{l}0.95 \\
0.94 \\
0.94 \\
1.10 \\
0.99 \\
1.02\end{array}$ & $\begin{array}{l}0.04 \\
0.04 \\
0.05 \\
0.14 \\
0.20 \\
0.21\end{array}$ & $\begin{array}{l}3.10 \\
3.36 \\
3.62 \\
5.11 \\
4.84 \\
4.69\end{array}$ \\
\hline Income & $\begin{array}{l}\text { Ln of Real GNP per capita, } \\
\text { in } 1987 \$ \text { US, calculated } \\
\text { using the Atlas method }\end{array}$ & World Bank & $\begin{array}{l}1965 \\
1970 \\
1975 \\
1980 \\
1985 \\
1990 \\
1995\end{array}$ & $\begin{array}{l}7.62 \\
7.68 \\
8.19 \\
8.38 \\
8.00 \\
8.28 \\
8.30\end{array}$ & $\begin{array}{l}1.46 \\
1.31 \\
1.23 \\
1.34 \\
1.27 \\
1.51 \\
1.55\end{array}$ & $\begin{array}{l}5.49 \\
5.63 \\
5.63 \\
5.33 \\
5.07 \\
5.23 \\
5.17\end{array}$ & $\begin{array}{r}9.45 \\
9.54 \\
9.81 \\
9.96 \\
9.75 \\
10.04 \\
10.22\end{array}$ \\
\hline Inequality & $\begin{array}{l}\text { Inequality, measured by the } \\
\text { gini coefficient. As in } \\
\text { Deininger and Squire, I } \\
\text { have added } 6.6 \text { to gini } \\
\text { coefficients based on } \\
\text { expenditure (instead of } \\
\text { income) }\end{array}$ & Deininger \& Squire & $\begin{array}{l}1965 \\
1970 \\
1975 \\
1980 \\
1985 \\
1990\end{array}$ & $\begin{array}{l}37.8 \\
40.3 \\
39.9 \\
38.1 \\
37.4 \\
38.0\end{array}$ & $\begin{array}{l}8.37 \\
9.45 \\
9.03 \\
8.36 \\
8.59 \\
9.03\end{array}$ & $\begin{array}{l}24.3 \\
25.1 \\
23.3 \\
21.5 \\
21.0 \\
23.3\end{array}$ & $\begin{array}{l}55.5 \\
57.7 \\
61.9 \\
57.8 \\
61.8 \\
59.6\end{array}$ \\
\hline $\begin{array}{l}\text { Male } \\
\qquad \text { Education }\end{array}$ & $\begin{array}{l}\text { Average years of secondary } \\
\text { schooling in the male } \\
\text { population aged over } 25\end{array}$ & Barro \& Lee & $\begin{array}{l}1965 \\
1970 \\
1975 \\
1980 \\
1985 \\
1990\end{array}$ & $\begin{array}{l}1.13 \\
1.27 \\
1.47 \\
1.79 \\
1.90 \\
2.16\end{array}$ & $\begin{array}{l}0.85 \\
0.86 \\
0.92 \\
1.06 \\
0.99 \\
1.02\end{array}$ & $\begin{array}{l}0.18 \\
0.35 \\
0.37 \\
0.57 \\
0.65 \\
0.73\end{array}$ & $\begin{array}{l}2.94 \\
3.27 \\
3.55 \\
5.07 \\
4.81 \\
4.85\end{array}$ \\
\hline$P P P I$ & $\begin{array}{l}\text { Price level of investment, } \\
\text { measured as the PPP of } \\
\text { investment/exchange rate } \\
\text { relative to the United } \\
\text { States }\end{array}$ & Heston \& Summers & $\begin{array}{l}1965 \\
1970 \\
1975 \\
1980 \\
1985 \\
1990\end{array}$ & $\begin{array}{l}76.7 \\
68.1 \\
86.4 \\
93.5 \\
61.2 \\
75.7\end{array}$ & $\begin{array}{l}22.7 \\
18.9 \\
24.6 \\
28.5 \\
16.3 \\
31.4\end{array}$ & $\begin{array}{l}40.8 \\
41.2 \\
36.5 \\
44.4 \\
31.9 \\
27.9\end{array}$ & $\begin{array}{r}119.2 \\
107.1 \\
130.7 \\
140.7 \\
94.3 \\
129.3\end{array}$ \\
\hline
\end{tabular}

Note: If the gini coefficient is not available for a given year, the observation is taken from the closest year in the five-year period ending in the stated year.

Sources: Barro \& Lee, the data set compiled in Barro and Lee (1996). Deininger \& Squire, the data set compiled in Deininger and Squire (1996). Heston \& Summers, the "Penn World Tables" version 5.6 described in Alan Heston and Robert Summers (1991). World Bank, "World*Data 1995" published by the World Bank and available on CD-ROM.

\section{Estimation}

There are a variety of different techniques that can be used to estimate equation (1). To evaluate which technique is optimal, it is necessary to consider three factors: the relationship between the country-specific effect and the regressors, the presence of a lagged endogenous variable (income), and the potential endogeneity of the other regressors.

The standard methods of panel estimation are fixed effects or random effects. For the purpose of estimating equation (1), the major difference between these two techniques is the information utilized to calculate the coefficients. The fixedeffects estimates are calculated from differences within each country across time; the randomeffects estimates are more efficient, since they incorporate information across individual countries as well as across periods. The major drawback with random effects is that it is consistent only if the country-specific effects are uncorrelated with the other explanatory variables. A Hausman specification test can evaluate whether this independence assumption is satisfied. 
TABLE 2-Gini CoefFicients

\begin{tabular}{|c|c|c|c|c|c|c|}
\hline Country & $1961-1965$ & 1966-1970 & $1971-1975$ & 1976-1980 & 1981-1985 & 1986-1990 \\
\hline Australia & - & - & - & 39.3 & 37.6 & 41.7 \\
\hline Bangladesh & 37.3 & 34.2 & 36.0 & 35.2 & 36.0 & 35.5 \\
\hline Belgium & - & - & - & 28.3 & 26.2 & 26.6 \\
\hline Brazil & - & 57.6 & 61.9 & 57.8 & 61.8 & 59.6 \\
\hline Bulgaria & - & - & - & - & 23.4 & 24.5 \\
\hline Canada & 31.6 & 32.3 & 31.6 & 31.0 & 32.8 & 27.6 \\
\hline Chile & - & 45.6 & 46.0 & 53.2 & - & - \\
\hline China & - & - & - & 32.0 & 31.4 & 34.6 \\
\hline Colombia & 一 & 52.0 & 46.0 & 54.5 & - & - \\
\hline Costa Rica & - & - & 44.4 & 45.0 & 47.0 & 46.1 \\
\hline Denmark & - & - & - & 31.0 & 31.0 & 33.2 \\
\hline Dominican Republic & - & - & - & 45.0 & 43.3 & 50.5 \\
\hline Finland & - & 31.8 & 27.0 & 30.9 & 30.8 & 26.2 \\
\hline France & 47.0 & 44.0 & 43.0 & 34.9 & 34.9 & - \\
\hline Germany & 28.1 & 33.6 & 30.6 & 32.1 & 32.2 & - \\
\hline Greece & - & - & - & - & 39.9 & 41.8 \\
\hline Hong Kong & - & - & 39.8 & 37.3 & 45.2 & 42.0 \\
\hline Hungary & - & - & - & 21.5 & 21.0 & 23.3 \\
\hline India & 37.7 & 37.0 & 35.8 & 38.7 & 38.1 & 36.3 \\
\hline Indonesia & - & - & - & 42.2 & 39.0 & 39.7 \\
\hline Ireland & - & - & 38.7 & 35.7 & - & - \\
\hline Italy & - & - & 39.0 & 34.3 & 33.2 & 32.7 \\
\hline Japan & 34.8 & 35.5 & 34.4 & 33.4 & 35.9 & 35.0 \\
\hline Korea (South) & 34.3 & 33.3 & 36.0 & 38.6 & 34.5 & 33.6 \\
\hline Malaysia & - & 50.0 & 51.8 & 51.0 & 48.0 & 48.4 \\
\hline Mexico & 55.5 & 57.7 & 57.9 & 50.0 & 50.6 & 55.0 \\
\hline Netherlands & - & - & 28.6 & 28.1 & 29.1 & 29.6 \\
\hline New Zealand & - & - & 30.0 & 34.8 & 35.8 & 40.2 \\
\hline Norway & 37.5 & 36.0 & 37.5 & 31.2 & 31.4 & 33.1 \\
\hline Pakistan & - & 36.5 & 38.1 & 38.9 & 39.0 & 38.0 \\
\hline Peru & - & - & - & - & 49.3 & 49.4 \\
\hline Philippines & - & - & 一 & - & 46.1 & 45.7 \\
\hline Poland & - & - & - & - & 25.3 & 26.2 \\
\hline Portugal & - & - & 40.6 & 36.8 & - & - \\
\hline Singapore & - & 一 & 41.0 & 40.7 & 42.0 & 39.0 \\
\hline Spain & - & - & 37.1 & 33.4 & 31.8 & 32.5 \\
\hline Sri Lanka & 47.0 & 37.7 & 35.3 & 42.0 & 45.3 & 36.7 \\
\hline Sweden & - & 33.4 & 27.3 & 32.4 & 31.2 & 32.5 \\
\hline Thailand & 41.3 & 42.6 & 41.7 & - & - & - \\
\hline Trinidad and Tobago & - & - & 51.0 & 46.1 & 41.7 & - \\
\hline Tunisia & - & - & 50.6 & 49.6 & 49.6 & 46.8 \\
\hline Turkey & - & 56.0 & 51.0 & - & - & - \\
\hline United Kingdom & 24.3 & 25.1 & 23.3 & 24.9 & 27.1 & 32.3 \\
\hline United States & 34.6 & 34.1 & 34.4 & 35.2 & 37.3 & 37.8 \\
\hline Venezuela & - & - & 47.7 & 39.4 & 42.8 & 53.8 \\
\hline Average & 37.8 & 40.3 & 39.9 & 38.1 & 37.4 & 38.0 \\
\hline
\end{tabular}

Note: Gini coefficient is taken from the latest available date within the given period.

A problem with both fixed effects and random effects, however, is that equation (1) contains a lagged endogenous variable (the income term). This is immediately apparent when the equation is rewritten with growth expressed as the difference in income levels and then Income $_{i, t-1}$ is added to both sides:
(2) Income $_{i t}=\beta_{1}$ Inequality $_{i, t-1}$

$+\gamma_{2}$ Income $_{i, t-1}$

$+\beta_{3}$ MaleEducation $_{i, t-1}$ 


$$
\begin{aligned}
& +\beta_{4} \text { FemaleEducation }_{i, t-1} \\
& +\beta_{5} \text { PPPI }_{i, t-1}+\alpha_{i}+\eta_{t}+u_{i t}
\end{aligned}
$$

with

$$
\gamma_{2}=\beta_{2}+1
$$

To simplify the following discussion, this can be written

$$
\text { (3) } y_{i t}=\gamma y_{i, t-1}+\mathbf{X}_{i, t-1}^{\prime} \mathbf{B}+\alpha_{i}+\eta_{t}+u_{i t} \text {. }
$$

Even if $y_{i, t-1}$ and $u_{i t}$ are not correlated, if $t$ does not approach infinity (which it clearly does not in this model where $t=6$ ), then estimation by fixed effects or random effects is not consistent (even as $n$ goes to infinity). Monte Carlo simulation shows that for panels with a comparable time dimension, the bias of the coefficient on the lagged dependent variable can be significant, although the bias for the coefficients on the other right-hand-side variables tends to be minor. ${ }^{10}$

One popular method of correcting for this bias is Chamberlain's $\pi$-matrix technique. ${ }^{11}$ The fundamental identifying condition for this estimator is the exogeneity of a large enough subset of the explanatory variables. In the model of equation (1), however, it is unlikely that this condition is satisfied. A whole branch of economics has investigated the Kuznets' relationship of how income might affect inequality, and recent work suggests that growth may free resources for investment in human capital, therefore raising education levels. This would leave only one variable $\left(P P P I_{i t}\right)$ for identification, which is clearly not sufficient. A Hausman specification test can evaluate whether the explanatory variables (other than income) are exogenous. $^{12}$

\footnotetext{
${ }^{10}$ For example, Ruth Judson and Ann L. Owen (1996) estimate that under fixed effects when $t=5$, the bias in the lagged dependent variable is over 50 percent, whereas the bias in the other coefficients is only about 3 percent.

${ }^{11}$ For details on this approach, see Gary Chamberlain (1984) or Bruno B. Crépon and Jacques Mairesse (1996).

${ }^{12}$ This test is developed in Caselli et al. (1996) and compares estimates obtained under Chamberlain's and
}

Manuel Arellano and Stephen R. Bond (1991) suggest an alternative estimation technique that corrects not only for the bias introduced by the lagged endogenous variable, but also permits a certain degree of endogeneity in the other regressors. ${ }^{13}$ This generalized method of moments (GMM) estimator first-differences each variable so as to eliminate the countryspecific effect and then uses all possible lagged values of each of the variables as instruments. More specifically, Arellano and Bond rewrite equation (3) as:

$$
\begin{aligned}
y_{i t}-y_{i, t-1}= & \gamma\left(y_{i, t-1}-y_{i, t-2}\right) \\
& +\left(\mathbf{X}_{i, t-1}^{\prime}-\mathbf{X}_{i, t-2}^{\prime}\right) \mathbf{B} \\
& +\left(u_{i t}-u_{i, t-1}\right),
\end{aligned}
$$

where all variables are now expressed as deviations from period means (to control for the period dummy variables). For period 3 , Arellano and Bond use $y_{i, 1}$ as an instrument for $\left(y_{i, 2}-y_{i, 1}\right)$, for period 4 they use $y_{i, 1}$ and $y_{i, 2}$ as instruments for $\left(y_{i, 3}-y_{i, 2}\right)$, etc., and follow the same procedure to create instruments for each differenced variable. Two critical assumptions must be satisfied for this estimator to be consistent and efficient. First, the $\mathbf{X}_{i, t-s}$ 's must be predetermined by at least one period: $E\left(\mathbf{X}_{i t}^{\prime} u_{i s}\right)=0$ for all $s>t$. Second, the error terms cannot be serially correlated: $E\left(u_{i, t} u_{i, t-s}\right)=0$ for all $s \geq 1$. Tests of both of these assumptions are performed below.

Table 3 reports estimates of equation (1) using fixed effects, random effects, Chamberlain's $\pi$-matrix procedure, and Arellano and Bond's GMM technique. Estimates vary significantly, based on which technique is utilized, so it is necessary to test the validity of the assumptions underlying each method. First, a Hausman specification test comparing the fixed-effects

\footnotetext{
Arellano and Bond's techniques. Each of the estimators is consistent if the explanatory variables are exogenous (and the other assumptions discussed previously are satisfied). If the explanatory variables are not exogenous, only the Arellano and Bond estimator is consistent.

${ }^{13}$ Caselli et al. (1996) also use this technique in a growth regression. A more detailed explanation of this procedure is available in an Appendix prepared by the author.
} 
TABle 3-Regression Results: Alternate Estimation Techniques

\begin{tabular}{|c|c|c|c|c|c|}
\hline \multirow[b]{2}{*}{$\begin{array}{l}\text { Estimation } \\
\text { method }\end{array}$} & \multicolumn{4}{|c|}{ Five-year periods } & \multirow{2}{*}{$\begin{array}{l}\text { Ten-year } \\
\text { periods: } \\
\text { fixed effects } \\
\text { (5) }\end{array}$} \\
\hline & $\begin{array}{l}\text { Fixed effects } \\
\text { (1) }\end{array}$ & $\begin{array}{c}\text { Random effects } \\
\text { (2) }\end{array}$ & $\begin{array}{l}\text { Chamberlain's } \\
\pi \text {-matrix } \\
\text { (3) }\end{array}$ & $\begin{array}{l}\text { Arellano and } \\
\text { Bond } \\
\text { (4) }\end{array}$ & \\
\hline Inequality & $\begin{array}{c}0.0036 \\
(0.0015)\end{array}$ & $\begin{array}{c}0.0013 \\
(0.0006)\end{array}$ & $\begin{array}{c}0.0016 \\
(0.0002)\end{array}$ & $\begin{array}{c}0.0013 \\
(0.0006)\end{array}$ & $\begin{array}{c}0.0013 \\
(0.0011)\end{array}$ \\
\hline Income & $\begin{array}{c}-0.076 \\
(0.020)\end{array}$ & $\begin{array}{c}0.017 \\
(0.006)\end{array}$ & $\begin{array}{c}-0.027 \\
(0.004)\end{array}$ & $\begin{array}{c}-0.047 \\
(0.008)\end{array}$ & $\begin{array}{c}-0.071 \\
(0.016)\end{array}$ \\
\hline Male Education & $\begin{array}{c}-0.014 \\
(0.031)\end{array}$ & $\begin{array}{c}0.047 \\
(0.015)\end{array}$ & $\begin{array}{c}0.018 \\
(0.010)\end{array}$ & $\begin{array}{c}-0.008 \\
(0.022)\end{array}$ & $\begin{array}{c}-0.002 \\
(0.028)\end{array}$ \\
\hline Female Education & $\begin{array}{c}0.070 \\
(0.032)\end{array}$ & $\begin{array}{c}-0.038 \\
(0.016)\end{array}$ & $\begin{array}{c}0.054 \\
(0.006)\end{array}$ & $\begin{array}{c}0.074 \\
(0.018)\end{array}$ & $\begin{array}{c}0.031 \\
(0.030)\end{array}$ \\
\hline$P P P$ & $\begin{array}{c}-0.0008 \\
(0.0003)\end{array}$ & $\begin{array}{c}-0.0009 \\
(0.0002)\end{array}$ & $\begin{array}{c}-0.0013 \\
(0.0000)\end{array}$ & $\begin{array}{c}-0.0013 \\
(0.0001)\end{array}$ & $\begin{array}{c}-0.0003 \\
(0.0003)\end{array}$ \\
\hline$R^{2}$ & 0.67 & 0.49 & & & 0.71 \\
\hline Countries & 45 & 45 & 45 & 45 & 45 \\
\hline Observations & 180 & 180 & 135 & 135 & 112 \\
\hline Period & $1965-1995^{a}$ & $1965-1995^{a}$ & 1970-1995 & $1970-1995$ & $1965-1995$ \\
\hline
\end{tabular}

Notes: Dependent variable is average annual per capita growth. Standard errors are in parentheses. $R^{2}$ is the within- $R^{2}$ for fixed effects and the overall- $R^{2}$ for random effects.

${ }^{a}$ Estimates are virtually identical for the period 1970-1995 (with 135 observations).

estimates of column 1 with the random-effects estimates of column 2 rejects the assumption required for random effects. ${ }^{14}$ As mentioned previously, however, both methods are inconsistent due to the presence of the lagged income term. Columns 3 and 4 correct for this problem. Another Hausman test rejects the exogeneity of the explanatory variables, suggesting that Chamberlain's technique used in column 3 is also inconsistent. ${ }^{15}$ Finally, several tests of the requirements underlying Arellano and Bond's estimates suggest that these assumptions are satisfied. Although there is no formal test of the first assumption, estimates obtained using instruments lagged by more than one period, extending the length of $t$, or regressing inequality on lagged growth, all suggest that the $\mathbf{X}_{i, t-s}$ 's are predetermined by at least one period. Tests for the second assumption, namely a test for second-order serial correlation and Sargan's test of overidentifying restrictions, are both satis-

\footnotetext{
${ }^{14}$ The test statistic is $\chi^{2}(5)=67.6$. This rejects the null hypothesis at any standard level of significance.

${ }^{15}$ The test statistic is $\chi^{2}(5)=29.3$. This rejects the null hypothesis at any standard level of significance.
}

fied. ${ }^{16}$ Therefore, although it is still possible that endogeneity between inequality and growth undermines the requirement that $E\left(\mathbf{X}_{i t}^{\prime} u_{i s}\right)=0$ for all $s>t$, evidence suggests that the estimates reported in column 4 are consistent and efficient, and the following discussion focuses on these estimates.

Not only do most of the coefficient estimates in column 4 agree with those traditionally reported in this literature, but most are highly significant. ${ }^{17}$ As predicted by models implying conditional convergence, the coefficient on ini-

\footnotetext{
${ }^{16}$ Details of these two tests are available in Arellano and Bond (1991). In the test for second-order serial correlation in the differenced equation, the test statistic is $N(0,1)=$ 0.44 , which is unable to reject the null (of no second-order serial correlation) at any standard level of significance. The Sargan test is also satisfied, although it is less meaningful since it requires that the error terms are independently and identically distributed (and error terms in this model are heteroskedastic).

${ }^{17}$ For example, a test that the coefficients on the explanatory variables are zero yields the statistic: $F(5,130)=$ 12.3. In the fixed-effects specification of column 1 , if the country and period dummies are included outright (instead of demeaning the variables), then a test of the null that all country effects are equal yields the statistic: $F(44,125)=$ 4.6 , and a test that all period dummies are zero yields the
} 
tial income is negative and significant. The coefficient on male education is negative (although not significant) and that on female education is positive and significant. Although this pattern of signs may not support traditional human capital theory, these coefficients are similar to those found in other growth models estimated using the same technique [such as Caselli et al. (1996)]. The coefficient on market distortions is negative and highly significant. The one unexpected result is the coefficient on inequality. No matter which estimation technique is utilized, this coefficient is never negative, as estimated in recent work examining the relationship between inequality and growth. Instead, the coefficient on inequality is always positive and significant at the 5-percent level. Not only is the sign surprising, but also the magnitude of the coefficient. A ten-point increase in a country's gini coefficient is correlated with a 1.3 percent increase in average annual growth over the next five years. ${ }^{18}$

\section{What Affects the Coefficient on Inequality?}

It is important to note that the coefficients in Table 3 are interpreted differently than in previous work on this subject. As mentioned above, earlier work utilized ordinary least squares (OLS) or instrumental variables (IV) to estimate some variant of the standard crosscountry growth regression. The resulting estimates of a negative coefficient on inequality suggested that countries with lower levels of inequality tend to have higher steady-state levels of income. These estimates do not directly assess a potentially more relevant question: how are changes in a country's level of inequality related to changes in that country's growth performance? The Arellano and Bond fixed-effects estimator, however, specifically addresses this question. It controls for a country's unobservable, time-invariant characteristics or "fixed ef-

statistic: $F(5,125)=16.8$. In each of these cases, the null is rejected at any standard level of significance.

${ }^{18}$ Ten points is the difference in inequality in 1985 between the United States and the United Kingdom and is also close to one standard deviation in this paper's sample. Note, however, that it is unlikely that any country's gini coefficient could increase by this magnitude in a short period of time. fect," and instead of analyzing differences in inequality and growth across countries, focuses on changes in these variables within each country across time. The resulting coefficient on inequality can therefore be interpreted as measuring the highly relevant relationship of how changes in inequality are related to changes in growth within a given country.

Another difference between the interpretation of this paper's results and that of earlier work is the time period under consideration. The standard cross-country growth regression estimates how initial inequality is related to growth over the next 25 or 30 years, thereby assessing a long-run relationship. Since this paper utilizes five-year panels, however, the coefficients in columns 1-4 reflect a short- or medium-run relationship. As an informal test whether this shorter-term, positive relationship between inequality and growth diminishes over time, column 5 estimates equation (1) based on ten-year panels. ${ }^{19}$ The coefficient on inequality remains positive, although it decreases substantially and becomes insignificant. These results must be interpreted cautiously because of the limited degrees of freedom available. Therefore, until inequality data becomes available for a longer time span, it is difficult to draw any conclusions about the long-term relationship between inequality and growth within a given country.

Is it just these differences in estimation technique and period length that cause the inequality coefficient in Table 3 to be consistently positive, whereas most work in the field finds it is negative? Or do other factors, such as sample selection or the improved inequality data, affect results? Column 1 in Table 4 reports Perotti's estimates, which are typical in this literature and could differ from those in Table 3 for five reasons. First, Perotti defines two variables differently. Second, Perotti's sample is larger and there could be a structural difference in the relationship

\footnotetext{
${ }^{19}$ I report only fixed-effects estimates since Arellano and Bond's technique requires observations across an additional period, so only two ten-year periods are available for estimation. As a result, a number of countries must be excluded from the sample and meaningful estimation is impossible. I focus on fixed effects not only because it focuses on withincountry differences, but also because random-effects estimation is rejected in favor of fixed effects.
} 
TAble 4-Regression Results: What AfFects the Coefficient on Inequality?

\begin{tabular}{|c|c|c|c|c|c|c|c|}
\hline $\begin{array}{l}\text { Definitions } \\
\text { and data set }\end{array}$ & $\begin{array}{c}\text { Perotti }{ }^{\mathrm{a}} \text { low } \\
\text { quality }\end{array}$ & $\begin{array}{l}\text { D\&S } S^{b} \text { low } \\
\text { quality }^{\mathrm{c}}\end{array}$ & $\begin{array}{l}\mathrm{D} \& \mathrm{~S}^{\mathrm{b}} \text { low } \\
\text { quality }^{\mathrm{c}}\end{array}$ & $\begin{array}{l}\text { D\&S } S^{b} \text { high } \\
\text { quality }\end{array}$ & $\begin{array}{c}\mathrm{D} \& \mathrm{~S}^{\mathrm{b}} \text { high } \\
\text { quality }\end{array}$ & $\begin{array}{l}\text { D\&S } \\
\text { quality }^{\mathrm{c}} \text { low }\end{array}$ & $\begin{array}{l}\text { D\&S } \\
\text { quality }\end{array}$ \\
\hline $\begin{array}{l}\text { Estimation } \\
\text { and period }\end{array}$ & $\begin{array}{c}\text { OLS } \\
\text { 25-year } \\
(1)\end{array}$ & $\begin{array}{c}\text { OLS } \\
\text { 25-year } \\
(2)\end{array}$ & $\begin{array}{c}\text { OLS } \\
\text { 25-year } \\
(3)\end{array}$ & $\begin{array}{c}\text { OLS } \\
\text { 25-year } \\
(4)\end{array}$ & $\begin{array}{c}\text { OLS } \\
25-\text { year } \\
(5)\end{array}$ & $\begin{array}{c}\text { Arellano \& } \\
\text { Bond 5-year } \\
\text { (6) }\end{array}$ & $\begin{array}{c}\text { Arellano \& } \\
\text { Bond 5-year } \\
(7)\end{array}$ \\
\hline Constant & $\begin{array}{r}-0.018 \\
(0.013)\end{array}$ & $\begin{array}{c}0.046 \\
(0.027)\end{array}$ & $\begin{array}{c}0.061 \\
(0.026)\end{array}$ & $\begin{array}{c}0.071 \\
(0.030)\end{array}$ & $\begin{array}{c}0.018 \\
(0.031)\end{array}$ & & \\
\hline Inequality & $\begin{array}{r}-0.118^{a} \\
(0.042)\end{array}$ & $\begin{array}{c}-0.0005 \\
(0.0002)\end{array}$ & $\begin{array}{c}-0.0005 \\
(0.0003)\end{array}$ & $\begin{array}{c}-0.0005 \\
(0.0003)\end{array}$ & $\begin{array}{c}0.0002 \\
(0.0003)\end{array}$ & $\begin{array}{c}-0.0001 \\
(0.0001)\end{array}$ & $\begin{array}{c}0.0013 \\
(0.0006)\end{array}$ \\
\hline Income & $\begin{array}{c}-0.002 \\
(0.001)\end{array}$ & $\begin{array}{c}-0.001 \\
(0.003)\end{array}$ & $\begin{array}{c}-0.002 \\
(0.003)\end{array}$ & $\begin{array}{c}-0.004 \\
(0.003)\end{array}$ & $\begin{array}{l}0.002 \\
(0.008)\end{array}$ & $\begin{array}{c}-0.053 \\
(0.013)\end{array}$ & $\begin{array}{c}-0.047 \\
(0.008)\end{array}$ \\
\hline $\begin{array}{l}\text { Male } \\
\quad \text { Education }\end{array}$ & $\begin{array}{c}0.031 \\
(0.008)\end{array}$ & $\begin{array}{c}0.040 \\
(0.008)\end{array}$ & $\begin{array}{c}0.039 \\
(0.008)\end{array}$ & $\begin{array}{c}0.037 \\
(0.009)\end{array}$ & $\begin{array}{c}0.023 \\
(0.007)\end{array}$ & $\begin{array}{c}0.047 \\
(0.014)\end{array}$ & $\begin{array}{c}-0.008 \\
(0.022)\end{array}$ \\
\hline $\begin{array}{l}\text { Female } \\
\quad \text { Education }\end{array}$ & $\begin{array}{c}-0.025 \\
(0.008)\end{array}$ & $\begin{array}{c}-0.035 \\
(0.008)\end{array}$ & $\begin{array}{c}-0.035 \\
(0.008)\end{array}$ & $\begin{array}{c}-0.034 \\
(0.009)\end{array}$ & $\begin{array}{c}-0.023 \\
(0.007)\end{array}$ & $\begin{array}{c}0.019 \\
(0.009)\end{array}$ & $\begin{array}{c}0.074 \\
(0.018)\end{array}$ \\
\hline$P P P$ & $\begin{array}{c}-0.002 \\
(0.006)\end{array}$ & $\begin{array}{c}-0.0001 \\
(0.0001)\end{array}$ & $\begin{array}{c}-0.0001 \\
(0.0001)\end{array}$ & $\begin{array}{c}-0.0001 \\
(0.0001)\end{array}$ & $\begin{array}{c}-0.0001 \\
(0.0001)\end{array}$ & $\begin{array}{c}-0.0011 \\
(0.0001)\end{array}$ & $\begin{array}{c}-0.0013 \\
(0.0001)\end{array}$ \\
\hline$R^{2}$ & 0.31 & 0.38 & 0.40 & 0.40 & 0.50 & & \\
\hline Countries & 67 & 63 & 45 & 45 & 45 & 45 & 45 \\
\hline Periods & 1 & 1 & 1 & 1 & 5 & 5 & 5 \\
\hline
\end{tabular}

Notes: Dependent variable is average annual per capita growth from 1970-1995. Standard errors are in parentheses. $R^{2}$ is the overall- $R^{2}$.

${ }^{a}$ Estimates reported in Perotti (1996). Variable definitions used by Perotti are different from those used in the rest of this paper. For example, Inequality is measured as the income share held by the middle class (a measure of equality) rather than by the gini coefficient (a measure of inequality) and I add the negative sign to facilitate comparisons. Also Perotti defines Income as initial income, whereas I use the log of initial income. Finally, I have translated Perotti's reported $t$-statistics into standard errors to facilitate comparison with my estimates in the rest of the table.

${ }^{\mathrm{b}} \mathrm{D} \& \mathrm{~S}$ is the data set compiled by Deininger and Squire (1996) and used throughout this paper. Inequality is measured by the gini coefficient.

${ }^{c}$ Low-quality data is average inequality in the unabridged Deininger and Squire data set. This includes statistics accepted as high quality as well as those not accepted.

between inequality and growth in the two samples. Third, Perotti's data on inequality are low quality and not subject to the stringent consistency requirements of the Deininger and Squire data set. Fourth, as discussed earlier, Perotti focuses on the relationship between inequality and growth over longer periods of time. Fifth, and finally, Perotti focuses on differences across countries (instead of within countries across time) and does not correct for time-invariant omittedvariable bias by estimating the countryspecific effects. Therefore, modifying one or more of these factors should explain why this paper finds the opposite relationship between inequality and growth than previously reported.

To test which of these modifications alters the sign of the coefficient on inequality, I make each change independently. First I examine the impact of different variable definitions. Instead of using the gini coefficient as a measure of Inequality, Perotti uses the income share held by the middle class as a measure of equality (and I add a negative sign to his coefficient to facilitate comparison with the other columns). The other variable defined differently is Income. This paper and virtually all other work on growth utilize the logarithm of initial income, whereas Perotti simply uses initial income. To isolate the effect of these different definitions, I use Perotti's sample (as close as possible using my data sources), low-quality measures of inequality, and cross-country estimation (OLS). The lowquality data are the unabridged data collected by Deininger and Squire, which include not only the consistent measures of inequality 
used throughout this paper, but also all of the inconsistent measures used in past work. ${ }^{20}$ Also, to use OLS, equation (1) is rewritten

$$
\begin{aligned}
\text { Growth }_{i}= & \alpha_{0}+\beta_{1} \text { Inequality }_{i} \\
& +\beta_{2} \text { Income }_{i} \\
& +\beta_{3} \text { MaleEducation }_{i} \\
& +\beta_{4} \text { FemaleEducation }_{i} \\
& +\beta_{5} \text { PPPI }_{i}+u_{i}
\end{aligned}
$$

where Growth $_{i}$ is average annual growth from 1970-1995 for country $i ; \alpha_{0}$ is a constant term that does not vary across countries; and In-

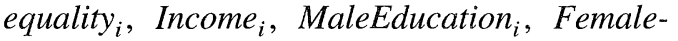
Education $_{i}$, and $P P P I_{i}$ are as previously defined and measured in $1970 .{ }^{21}$ Estimates of equation (5) obtained utilizing this paper's definitions, Perotti's sample, and the low-quality data set are reported in column 2 of Table 4. A comparison with column 1 shows that, although the coefficients on the variables defined differently do change, altering definitions does not change Perotti's key result: inequality has a significant negative relationship with growth.

Second, to test whether sample selection affects the results, column 3 uses the same definitions, low-quality data, and OLS framework as in column 2, but for the same set of countries as in column 7 (which replicates the central results reported in the last section). The coefficient on inequality barely changes (falling from -0.00050 to -0.00047 ), and although its standard error increases slightly (from 0.00022 to 0.00027), a Chow test strongly rejects any structural difference between the countries included

\footnotetext{
${ }^{20}$ When more than one observation on inequality is available per country in a given year, I average all available observations. The resulting low-quality data contain all but four countries in Perotti's sample. I do not use Perotti's low-quality measures of inequality since his data set does not contain observations across time, which are necessary for the following comparisons.

${ }^{21}$ I estimate growth from 1970-1995 (with explanatory variables from as close to 1970 as possible) so that these estimates are directly comparable with the central results in column 7. Estimates of growth from 1965-1995 (using explanatory variables from 1965) are virtually identical.
}

in Perotti's sample and those excluded from my sample. $^{22}$

Third, to test for the impact of reducing measurement error, I utilize the same variable definitions, sample, and OLS framework as in column 3 , but replace the low-quality inequality statistics with the more consistent measures from the high-quality data set. Results are reported in column 4. Reducing measurement error slightly strengthens the negative effect of inequality on growth (from -0.00047 to $-0.00049) .{ }^{23}$ This is not surprising since random measurement error biases coefficient estimates toward zero. The standard error changes even less, suggesting that either measurement error is not a significant problem in columns $1-3$, or the Deininger and Squire selection criteria do not significantly minimize any error.

Fourth, to see whether period length affects the relationship between inequality and growth, I utilize the same variable definitions and sample as in columns 4 and 7, but use the panel data that include statistics for five-year periods. Then I use OLS to estimate the same cross-country growth model of equation (5). I do not firstdifference or express the variables as deviations from country or period means, so I do not control for any omitted-variable bias. Results using the high-quality measures of inequality are reported in column 5 (and are virtually identical to those based on the low-quality data). The coefficient on inequality is now positive (although insignificant), suggesting that the length of the period under consideration does affect the relationship between inequality and growth.

Finally, to test for the effect of correcting for time-invariant omitted-variable bias, I utilize the same variable definitions, sample, and lowquality data as in column 3 , and the shorter periods of column 5, but estimate the panel model of equation (1) rather than the crosscountry model of equation (5). The results based on Arellano and Bond's estimator are

\footnotetext{
22 The impact of sample selection is further investigated in the sensitivity analysis.

${ }^{23}$ It is worth noting that this estimate is virtually identical to that in Deininger and Squire (1998), Table 3. They estimate a cross-country growth model using the same highquality measures of inequality, but with a different specification and much larger sample.
} 
reported in column 6 . The coefficient on inequality is insignificant and close to zero.

This set of comparisons reported in Table 4 has several strong implications. Column 2 shows that the positive effect of inequality on growth found in column 7 is not an artifact of variable definition or model specification. Column 3 indicates that sample selection has little influence (at least in a comparison with earlier work), and Column 4 reveals that minimizing measurement error has little impact in the crosscountry framework. Column 5 shows that in the five-year periods, when I do not control for the country- or period-specific effects, there is no significant relationship between inequality and growth. Correcting for time-invariant omittedvariable bias in column 6 , but using the lowquality measures of inequality, also yields no significant relationship. When this panel estimation technique is combined with the more consistent measures of inequality in column 7 , however, the relationship between inequality and growth is positive and significant. It is not surprising that minimizing measurement error is more important in panel than cross-country estimation; the correlation between the random term in initial inequality and the disturbance in the growth regression would be larger over 5year than 30 -year periods. ${ }^{24}$

\section{Sensitivity Analysis}

Since this positive relationship between inequality and growth challenges previous econometric work, and also since sample selection may influence the coefficient estimates, this section thoroughly tests the robustness of these results. ${ }^{25}$ It estimates a number of variations of the model estimated in Table 3, testing whether the positive relationship between inequality and growth persists across different samples, variable definitions, and model specifications. This section uses Arellano and Bond's methodology whenever possible, but in several cases when the variation being tested limits sample or pe-

\footnotetext{
${ }^{24}$ Also note that measurement error has the predicted effect in the panel framework: it biases the coefficient on inequality toward zero.

${ }^{25}$ See Ross E. Levine and David Renelt (1992) for a discussion of the importance of sensitivity tests in crosscountry growth regressions and a detailed set of such tests.
}

riod availability, utilizes the computationally less stringent fixed effects.

One potential problem with the results reported previously is sample selection. Because of the limited availability of inequality statistics, sample selection is always a problem in estimates of the relationship between inequality and growth. This problem is magnified by the use of panel estimation, which requires observations across time for each country, as well as across countries. Moreover, since only 45 countries are included, a group of outliers could have a large impact. Even more important, as discussed in Section II, period, regional, and country coverage are highly unrepresentative. If the selection mechanism is nonignorable (i.e., if there is some relationship between the independent variables and the countries and/or periods which are included) then coefficient estimates may be inconsistent and inefficient. ${ }^{26}$ Utilizing a fixed-effects estimator instead of random effects should minimize this problem, but it is still necessary to test for the influence of sample selection.

First, I test for the effect of removing outliers. I estimate the basic model removing one country at a time, removing the five observations farthest above and below the country mean for each variable, and then removing the five countries with the lowest and highest average inequality, income, or growth. ${ }^{27}$ In each case, although the value of the coefficient on inequality does fluctuate, the coefficient always remains positive and significant. A related concern is that different countries are included in each period. To control for this effect, I reestimate the basic model for a variety of different periods but only include countries that have observations for each period. For example, I estimate growth from 1975-1995 for the 24 countries with observations across all four periods, or growth from 1970-1990 for the 17 countries with data for each of these years. Once again, the coefficient on inequality is always positive and significant at the 5-percent level.

A similar concern is that if the model's coefficients change over time, then the pooling required to estimate fixed effects would not be appropriate

\footnotetext{
${ }^{26}$ See Marno Verbeek and Theo Nijman (1996) for a discussion of selection bias and its resultant problems.

${ }^{27}$ To conserve space, these results and several others referred to in the remainder of this section are not included in the tables. They are available from the author on request.
} 
and parameter estimates would be biased and inconsistent. This concern is especially valid since tests based on the OLS estimation of equation (5) for different periods suggest that the slope coefficients are not constant across time. Removing any single period from the fixed-effects model or estimating the model for any subset of periods, however, does not significantly change the inequality coefficient. Moreover, when country and period dummies are included in the regression, tests are no longer able to reject the equality of the coefficients across periods. ${ }^{28}$ These results not only support the assumptions required for pooling, but further suggest that omitted-variable bias is a significant problem in this cross-country framework.

Next, I examine how the sample's unbalanced regional coverage affects results. I reestimate equation (1), excluding countries from East Asia, Latin America, and the OECD. The resulting inequality coefficients are reported near the top of Table 5. No matter which of these regions is excluded from the sample, the relationship between inequality and growth remains positive and significant. ${ }^{29}$

Related to this unbalanced regional coverage is another potential problem with the sample: the representation of very poor countries is extremely limited. This is not surprising; wealthier countries tend to keep more accurate statistics and are therefore more likely to have enough consistent mea-

\footnotetext{
${ }^{28}$ For example, I estimate equation (1) using OLS (i.e., without dummy variables) and then add the country and period dummies. In each case I perform a test of structural change between the first half of the sample (1965-1980) and the second half of the sample (1980-1995). When I use OLS, I strongly reject the null hypothesis of the equality of the slope coefficients across the two periods, with the test statistic $F(5,168)=9.5$. When I include the country and period dummies, I am unable to reject the null hypothesis, with the test statistic $F(5,120)=1.7$ (and a 5-percent critical value of 2.2). I am also unable to reject the null of the equality of all coefficients (including country dummies) across the two periods, with a test statistic $F(50,76)=0.5$ (and a 5-percent critical value of 1.5).

${ }^{29}$ In several of these tests, standard errors decrease significantly when the sample is abridged. This is not unusual when the Arellano and Bond estimator is used with small samples, because the variance-covariance matrix used in the second stage is only asymptotically efficient. Tests comparing the first-stage and second-stage estimates, however, suggest that this is not a problem and estimates are unbiased. Moreover, fixed-effects estimates of the inequality coefficient are always positive and significant, with $t$ statistics in the standard range (between 2 and 4 ).
}

sures of inequality to be included in the sample. The relationship between inequality and growth, however, could depend on a country's stage of development. I test for this by experimenting with different functional forms, such as including a squared and/or cubed term for inequality. Results suggest that the relationship between inequality and growth is, in fact, the linear model specified in equation (1). As an alternate test, I divide the sample into wealthy and poor countries, based on initial income, and then reestimate equation (1) for each group. ${ }^{30}$ The middle of Table 5 shows that no matter which division is utilized, the relationship between inequality and growth remains positive in each group. In every case, I am unable to reject the null of the equality of coefficients across low-income and high-income countries.

In addition to unbalanced sample composition, another concern with this paper is that variable definitions could affect results. I reestimate the model for different definitions of education, income, market distortions, and/or inequality. For example, as alternate measures of education, I use enrollment rates or total years of schooling in primary or secondary education. As other measures of income or market distortions, I use (respectively) GDP per capita or the log of the black market premium. Finally, as alternate measures of inequality, I utilize two ratios of income shares or the negative of the income share held by the middle class. The bottom of Table 5 reports estimates for these other measures of inequality and shows that changing this variable definition does not affect the main results. ${ }^{31}$ Another concern with each of these measures of inequality, including the gini coefficient, is that even in this more consistent data set, different sources are occasionally utilized for the same country. The final row of Table 5 therefore reestimates the basic model, using only measures of inequality from the same source for each country. Once again, the coefficient on inequality remains positive and significant.

\footnotetext{
${ }^{30}$ Results do not change if I divide the sample into wealthy and poor countries based on final per capita income or average per capita income. I focus on fixed effects due to the small sample size of most groups.

${ }^{31} \mathrm{I}$ do not report results using alternate measures of education, income, or market distortions, since these changes have virtually no impact on the inequality coefficient. These estimates are available from the author.
} 
TABle 5-Sensitivity Analysis: Country Groups AND INEQUality Definitions ${ }^{\mathrm{a}}$

\begin{tabular}{|c|c|c|c|c|c|c|}
\hline & $\begin{array}{l}\text { Coefficient on } \\
\text { INEQ }\end{array}$ & $\begin{array}{l}\text { Standard } \\
\text { error }^{\mathrm{b}}\end{array}$ & Countries & Observations & $\begin{array}{l}\text { Period of } \\
\text { growth }\end{array}$ & $\begin{array}{l}\text { Estimation } \\
\text { technique }^{\text {b }}\end{array}$ \\
\hline \multicolumn{7}{|l|}{ Standard analysis } \\
\hline Whole sample & 0.0013 & $(0.0006)$ & 45 & 135 & 1970-1995 & $\mathrm{A} \& \mathrm{~B}$ \\
\hline Whole sample & 0.0036 & $(0.0015)$ & 45 & 180 & $1965-1995$ & FE \\
\hline \multicolumn{7}{|l|}{ Regional groups $^{\mathrm{c}}$} \\
\hline Excluding East Asia & 0.0039 & $(0.0000)$ & 38 & 115 & 1970-1995 & $\mathrm{A} \& \mathrm{~B}$ \\
\hline Excluding Latin America & 0.0025 & $(0.0003)$ & 36 & 111 & 1970-1995 & A\&B \\
\hline Excluding OECD & 0.0045 & $(0.0022)$ & 25 & 97 & $1965-1995$ & FE \\
\hline \multicolumn{7}{|l|}{ Income groups ${ }^{\mathrm{d}}$} \\
\hline Income $<\$ 1000$ & 0.0056 & $(0.0032)$ & 11 & 48 & $1.965-1995$ & $\mathrm{FE}$ \\
\hline Income $>\$ 1000$ & 0.0024 & $(0.0016)$ & 34 & 132 & $1965-1995$ & $\mathrm{FE}$ \\
\hline Income $<\$ 3000$ & 0.0061 & $(0.0021)$ & 23 & 90 & $1965-1995$ & $\mathrm{FE}$ \\
\hline Income $>\$ 3000$ & 0.0018 & $(0.0021)$ & 22 & 90 & $1965-1995$ & $\mathrm{FE}$ \\
\hline Income $<\$ 6000$ & 0.0042 & $(0.0020)$ & 34 & 126 & $1965-1995$ & $\mathrm{FE}$ \\
\hline Income $>\$ 6000$ & 0.0022 & $(0.0017)$ & 11 & 54 & 1965-1995 & $\mathrm{FE}$ \\
\hline \multicolumn{7}{|l|}{ Inequality definitions $\mathrm{s}^{\mathrm{e}}$} \\
\hline $20 / 40$ ratio & 0.0164 & $(0.0005)$ & 43 & 118 & 1970-1995 & A\&B \\
\hline $20 / 20$ ratio & 0.0062 & $(0.0001)$ & 43 & 118 & 1970-1995 & $A \& B$ \\
\hline -Middle Class & 0.1710 & $(0.0212)$ & 43 & 118 & $1970-1995$ & $A \& B$ \\
\hline Adjusted inequality & 0.0053 & $(0.0020)$ & 37 & 122 & $1965-1995$ & FE \\
\hline
\end{tabular}

${ }^{\text {a }}$ Complete results for each of these specifications is available from the author in an Appendix.

${ }^{\mathrm{b}} \mathrm{A} \& \mathrm{~B}$, Arellano and Bond. FE, fixed effects. A\&B is used whenever possible. FE is used when the analysis restricts the sample so that A\&B is not feasible. See footnote 29 for an explanation of why standard errors decrease significantly for abridged samples with the A\&B estimator.

${ }^{c}$ Regional divisions follow Barro and Lee (1997). The countries included in each region are: East Asia: Hong Kong, Indonesia, Korea, Malaysia, Philippines, Singapore, and Thailand; Latin America: Brazil, Chile, Colombia, Costa Rica, Dominican Republic, Mexico, Peru, Trinidad and Tobago, and Venezuela; OECD/High Income: Australia, Belgium, Canada, Denmark, Finland, France, Germany, Greece, Ireland, Italy, Japan, Netherlands, New Zealand, Norway, Portugal, Spain, Sweden, Turkey, United Kingdom, and United States.

${ }^{d}$ Countries are categorized based on GNP per capita in 1965. Income is measured in 1987 \$US.

e $20 / 40$ ratio is the income share held by the richest 20 percent of the population to the share held by the poorest 40 percent. $20 / 20$ ratio is the share held by the richest 20 percent to that held by the poorest 20 percent. - Middle Class is the negative of the income share held by the third and fourth wealthiest quintiles. Adjusted inequality uses only gini coefficients from the same source for each country.

As a final sensitivity test, I estimate a variety of different model specifications. In each case, I use three different estimation techniques: OLS to estimate the cross-country model standard in this literature; OLS to estimate the pooled specification; and fixed effects to estimate the panel model central to this paper. I focus on fixed effects for the panel estimation because in many of these specifications the sample becomes so truncated that estimation based on Arellano and Bond's technique is not possible. The Appendix lists additional variable definitions and Table 6 reports estimates. ${ }^{32}$ Row 1 replicates this paper's cen-

\footnotetext{
${ }^{32}$ Because of the large amount of data required to replicate each of these studies, all variable sources and definitions are not identical to those utilized in the original papers. Instead, all variables for this comparison are drawn from Barro and Lee (1997), and in the few cases where the same
}

tral model for the truncated sample utilized for these regressions; rows 2-5 use models from four well-known papers which estimate the effect of inequality on growth; columns 6-10 add inequality to models frequently cited in the more general growth literature. ${ }^{33}$ These results

variable is not available, the closest possible alternative is utilized. Most of these variables are available only through 1985 , so the dependent variable in these regressions is growth from 1965-1990. Also note that Alesina and Perotti (1994) use a dummy variable for democracy, but since this dummy variable is constant for most countries across time, I replace it with political instability.

${ }^{33}$ These specifications are only a subset of those estimated in these papers. I have also estimated the other variants of these basic models-and the estimated inequality coefficients follow the same patterns as reported in Table 6 . The results reported in the table were chosen to represent the widest variety of specifications previously utilized in this literature. 
Table 6-Sensitivity Analysis: Alternate Specifications

\begin{tabular}{|c|c|c|c|c|c|c|c|}
\hline \multirow[b]{2}{*}{ Specification source } & \multirow[b]{2}{*}{$\begin{array}{l}\text { Independent variables other } \\
\text { than Inequality and Income }\end{array}$} & \multicolumn{3}{|c|}{ Coefficient on inequality ${ }^{a}$} & \multirow[b]{2}{*}{ Countries } & \multirow[b]{2}{*}{ Observations } & \multirow[b]{2}{*}{$R^{2}$} \\
\hline & & $\begin{array}{c}\text { X-country } \\
\text { OLS }^{b}\end{array}$ & $\begin{array}{l}\text { Pooled } \\
\text { OLS }^{\mathrm{c}}\end{array}$ & $\begin{array}{l}\text { Panel } \\
\text { FE }^{\mathrm{d}}\end{array}$ & & & \\
\hline $\begin{array}{l}\text { (1) This paper \& } \\
\text { Perotti (1996) }\end{array}$ & $\begin{array}{l}\text { FemaleEducation, Male } \\
\text { Education, PPPI }\end{array}$ & $\begin{array}{c}-0.0004 \\
(0.0003)\end{array}$ & $\begin{array}{c}0.0004 \\
(0.0005)\end{array}$ & $\begin{array}{c}0.0048 \\
(0.0017)\end{array}$ & 45 & 144 & 0.73 \\
\hline $\begin{array}{l}\text { (2) Alesina \& Perotti } \\
\text { (1994) }\end{array}$ & Prim, Pstab & $\begin{array}{l}-0.0005 \\
(0.0004)\end{array}$ & $\begin{array}{l}-0.0000 \\
(0.0006)\end{array}$ & $\begin{array}{c}0.0034 \\
(0.0016)\end{array}$ & 40 & 104 & 0.82 \\
\hline $\begin{array}{l}\text { (3) Birdsall et al. } \\
\text { (1995) }\end{array}$ & $\begin{array}{l}\text { Assa, Gcons, PPPI, Prim, } \\
\quad \text { Revo, Sec }\end{array}$ & $\begin{array}{c}-0.0021 \\
(0.0005)\end{array}$ & $\begin{array}{c}-0.0001 \\
(0.0008)\end{array}$ & $\begin{array}{c}0.0041 \\
(0.0017)\end{array}$ & 38 & 102 & 0.83 \\
\hline $\begin{array}{l}\text { (4) Deininger \& } \\
\text { Squire (1998) }\end{array}$ & $\begin{array}{l}\text { Bmp, FemaleEducation, } \\
\text { Inv, MaleEducation, } \\
\text { PPPI }\end{array}$ & $\begin{array}{r}-0.0007 \\
(0.0003)\end{array}$ & $\begin{array}{c}0.0002 \\
(0.0005)\end{array}$ & $\begin{array}{c}0.0038 \\
(0.0017)\end{array}$ & 43 & 141 & 0.75 \\
\hline (5) Perotti (1996) & $\begin{array}{l}\text { FemaleEducation, } \\
\text { MaleEducation, Pop }> \\
\quad 65, \text { PPPI }\end{array}$ & $\begin{array}{r}-0.0005 \\
(0.0005)\end{array}$ & $\begin{array}{c}0.0006 \\
(0.0007)\end{array}$ & $\begin{array}{c}0.0044 \\
(0.0016)\end{array}$ & 42 & 140 & 0.74 \\
\hline $\begin{array}{l}\text { (6) Levine \& Renelt } \\
\text { (1992) }\end{array}$ & $\begin{array}{l}\text { Gcons, Inv, Popgr, Prim, } \\
\quad \text { Revcp, Sec }\end{array}$ & $\begin{array}{c}-0.0015 \\
(0.0005)\end{array}$ & $\begin{array}{c}0.0001 \\
(0.0008)\end{array}$ & $\begin{array}{c}0.0035 \\
(0.0018)\end{array}$ & 38 & 102 & 0.83 \\
\hline $\begin{array}{l}\text { (7) Levine \& Renelt } \\
\text { (1992) }\end{array}$ & $\begin{array}{l}\text { Bmp, Exp, Gcons, Inv, } \\
\quad \text { Popgr, Prim, Revcp, Sec }\end{array}$ & $\begin{array}{r}-0.0013 \\
(0.0004)\end{array}$ & $\begin{array}{c}0.0006 \\
(0.0008)\end{array}$ & $\begin{array}{c}0.0026 \\
(0.0017)\end{array}$ & 37 & 100 & 0.87 \\
\hline $\begin{array}{l}\text { (8) Barro \& Sala-i- } \\
\text { Martin (1995) }\end{array}$ & $\begin{array}{l}\text { Bmp, FemaleEducation, } \\
\text { Fhigh, Gcons, } \\
\text { GDP*HM, Goved, Inv, } \\
\text { Lifex, MaleEducation, } \\
\text { Mhigh, Pstab, Tot }\end{array}$ & $\begin{array}{r}-0.0007 \\
(0.0004)\end{array}$ & $\begin{array}{c}0.0016 \\
(0.0006)\end{array}$ & $\begin{array}{c}0.0037 \\
(0.0018)\end{array}$ & 38 & 102 & 0.86 \\
\hline $\begin{array}{l}\text { (9) Caselli et al. } \\
\text { (1996) }\end{array}$ & $\begin{array}{l}\text { Assa, Bmp, } \\
\text { FemaleEducation, } \\
\text { Gcons, Inv, Lifex, } \\
\text { MaleEducation }\end{array}$ & $\begin{array}{c}-0.0008 \\
(0.0003)\end{array}$ & $\begin{array}{c}0.0010 \\
(0.0007)\end{array}$ & $\begin{array}{c}0.0026 \\
(0.0017)\end{array}$ & 38 & 102 & 0.84 \\
\hline $\begin{array}{l}\text { (10) Caselli et al. } \\
\text { (1996) }\end{array}$ & $\begin{array}{l}\text { Assa, Bmp, } \\
\text { FemaleEducation, } \\
\text { Gcons, Inv, } \\
\text { MaleEducation, Tot }\end{array}$ & $\begin{array}{l}-0.0008 \\
(0.0003)\end{array}$ & $\begin{array}{c}0.0008 \\
(0.0006)\end{array}$ & $\begin{array}{c}0.0028 \\
(0.0017)\end{array}$ & 38 & 102 & 0.84 \\
\hline
\end{tabular}

${ }^{a}$ Dependent variable is average annual growth from 1965-1990. Standard errors are in parentheses.

${ }^{\mathrm{b}}$ Cross-country estimation. Independent variables are from 1965 or the earliest available year thereafter.

${ }^{\mathrm{c}}$ Data divided into five-year panels. Estimation obtained using OLS on this pooled data. Country and period dummies are not included.

${ }^{\mathrm{d}}$ Data divided into five-year panels. Estimation obtained using fixed effects (including both country and period dummies).

show that when OLS is used in the crosscountry framework, inequality is estimated to have a negative relationship with economic growth. This relationship is significant in about three-quarters of the specifications. When the data are pooled into five-year periods, the relationship between inequality and growth fluctuates between positive and negative, and is usually insignificant and close to zero. When country and period effects are incorporated in this pooled model, the relationship between inequality and growth is always positive and significant (at the 10-percent level and usually at the 5-percent level). It is noteworthy that the models in rows $1-5$ were previously used to show that inequality has a negative effect on growth, but under the estimation technique used in this paper, the relationship is not only positive, but always significant at the 5-percent level. As a whole, these comparisons suggest that the positive relationship between inequality and growth reported in this paper is not driven by model specification.

\section{Conclusion}

The results reported in this paper clearly challenge the current belief that income inequality has 
a negative effect on economic growth. Previous work on this topic was limited by the availability of cross-country measures of inequality. This paper uses an improved set of inequality statistics not only to reduce measurement error, but also to utilize panel estimation to control for timeinvariant omitted variables. By focusing on a generalized method of moments technique developed by Arellano and Bond, this paper directly estimates how changes in inequality are correlated with changes in growth within a given country. Results suggest that in the short and medium term, an increase in a country's level of income inequality has a significant positive relationship with subsequent economic growth. This relationship is highly robust across samples, variable definitions, and model specifications, with the one caveat that it may not apply to very poor countries.

A series of these sensitivity tests (reported in Table 6) shows that for a wide range of model specifications, pooled OLS estimates of the five-year relationship between inequality and growth are insignificant. When country effects are incorporated into this pooled model, however, the relationship between inequality and growth becomes positive and significant. This suggests that country-specific, time-invariant, omitted variables generate a significant negative bias in the estimated inequality coefficient. What causes this bias? Although it is impossible to predict the sign of the bias generated by an omitted variable in this multivariate context, theory suggests a number of variables that could generate a strong negative bias in the univariate context. Some examples are: higher levels of corruption (which tend to be positively correlated with inequality and negatively correlated with growth); a higher share of government spending on basic health care or primary education; or better-quality public education (which all tend to be negatively correlated with inequality and positively correlated with growth). Future research could try to identify whether these omitted variables, or any others, generate the negative bias in the inequality coefficient in cross-country growth regressions.

Taken as a whole, this paper's finding of a positive relationship between inequality and growth has disappointing implications. Countries may face a trade-off between reducing inequality and improving growth performance. It is too soon, however, to draw any definitive policy conclusions. Sample selection, endogeneity, and serial correlation could still influence estimates. Not enough data are available to accurately measure this relationship for very poor countries. Although the data on inequality are markedly improved, measurement error may still be a problem, and although panel estimation adjusts for time-invariant omitted variables, it does not control for omitted variables that vary across time. Both of these problems could be aggravated by the use of panel estimation. Moreover, these estimates do not directly contradict the previously reported negative relationship between inequality and growth. Earlier work utilizes cross-country growth regressions to estimate the long-term relationship between these two variables across countries. This paper focuses on the shortand medium-term relationship within individual countries. Sufficient data are not currently available to estimate this within-country relationship over periods longer than ten years, and it is possible that the strong positive relationship between inequality and growth could diminish (or even reverse) over significantly longer periods. ${ }^{34}$ It is also possible that the within-country and cross-country relationships between inequality and growth work through very different channels and are of opposite signs. Therefore, the estimates in this paper should be interpreted as suggesting that the relationship between inequality and growth is far from resolved, and that further careful reassessment of the sign, direction, and strength of the linkages between these two variables is necessary.

Equally important, even if this short-term, within-country, positive relationship between inequality and growth is proven to be robust, this paper does not investigate how these two variables and their underlying determinants are interconnected. The introduction outlines several theories that could explain a positive association between inequality and growth, but none

\footnotetext{
${ }^{34}$ Some of the theoretical channels explaining why inequality might have a negative impact on growth would have a stronger impact over longer periods of time. For example, if higher levels of inequality and the resultant liquidity constraints limit investment in education, the negative impact on growth would be greater in the long term.
} 
has been subject to rigorous empirical tests. Therefore, this paper suggests the need for not only a further careful reassessment of the reduced-form relationship between these two variables, but also further theoretical and empirical work evaluating the channels through which inequality, growth, and any other variables are related.

APPendix: Variable Definitions for Alternate Specifications

\begin{tabular}{|c|c|}
\hline Variable & Definition \\
\hline Assa & $\begin{array}{l}\text { Number of assassinations per million } \\
\text { population per year }\end{array}$ \\
\hline$B m p$ & $\begin{array}{l}\text { The log of }(1+\text { black market premium). } \\
\text { Black market premium measured as (black } \\
\text { market exchange rate/official exchange } \\
\text { rate })-1\end{array}$ \\
\hline $\operatorname{Exp}$ & $\begin{array}{l}\text { Ratio of exports to GDP (in current } \\
\text { international prices) }\end{array}$ \\
\hline Fhigh & $\begin{array}{l}\text { Average years of higher schooling in the } \\
\text { female population aged over } 25\end{array}$ \\
\hline Gcons & $\begin{array}{l}\text { Ratio of real government consumption } \\
\text { expenditure net of spending on defense } \\
\text { and education to real GDP }\end{array}$ \\
\hline$G D P^{*} H M$ & $\begin{array}{l}\text { Interactive term between a country's per } \\
\text { capita income and human capital. } \\
\text { Calculated as Income } * \text { (MaleEducation }+ \\
\text { FemaleEducation }+ \text { Mhigh }+ \text { Fhigh }+ \\
\text { Lifex) where Income, MaleEducation, and } \\
\text { FemaleEducation are defined in Table } 1\end{array}$ \\
\hline Goved & $\begin{array}{l}\text { Ratio of total nominal government } \\
\text { expenditure on education to nominal GDP }\end{array}$ \\
\hline $\operatorname{Inv}$ & $\begin{array}{l}\text { Ratio of real domestic investment (private } \\
\text { plus public) to real GDP }\end{array}$ \\
\hline Lifex & Life expectancy at birth \\
\hline Mhigh & $\begin{array}{l}\text { Average years of higher schooling in the } \\
\text { male population aged over } 25\end{array}$ \\
\hline Popgr & Growth rate of the population \\
\hline Pop $>65$ & Proportion of the population aged over 65 \\
\hline Prim & $\begin{array}{l}\text { Total gross enrollment ratio for primary } \\
\text { education }\end{array}$ \\
\hline Pstab & $\begin{array}{l}\text { Political instability. Calculated as }(0.5 * \text { Assa }) \\
\quad+(0.5 * \text { Revo })\end{array}$ \\
\hline $\operatorname{Revcp}$ & $\begin{array}{l}\text { Total number of revolutions and coups per } \\
\text { year }\end{array}$ \\
\hline Revo & Total number of revolutions per year \\
\hline $\mathrm{Sec}$ & $\begin{array}{l}\text { Total gross enrollment ratio for secondary } \\
\text { education }\end{array}$ \\
\hline Tot & $\begin{array}{l}\text { Growth in the terms of trade (or the terms of } \\
\text { trade shock). Measured as the growth rate } \\
\text { of export prices minus the growth rate of } \\
\text { import prices }\end{array}$ \\
\hline
\end{tabular}

Source: All data are taken from Barro and Lee (1997), except the variables used in the base regression and defined in Table 1.

\section{REFERENCES}

Alesina, Alberto and Perotti, Roberto. "The Political Economy of Growth: A Critical Survey of the Recent Literature." World Bank Economic Review, September 1994, 8(3), pp. 351-71.

Alesina, Alberto and Rodrik, Dani. "Distributive Politics and Economic Growth." Quarterly Journal of Economics, May 1994, 109(2), pp. 465-90.

Anand, Sudhir and Kanbur, S. M. Ravi. "Inequality and Development: A Critique." Journal of Development Economics, June 1993, 41(1), pp. 19-43.

Arellano, Manuel and Bond, Stephen R. "Some Tests of Specification for Panel Data: Monte Carlo Evidence and an Application to Employment Equations." Review of Economic Studies, April 1991, 58(2), pp. 27797.

Barro, Robert J. and Lee, Jong Wha. "International Measures of Schooling Years and Schooling Quality." American Economic Review, May 1996 (Papers and Proceedings), 86(2), pp. 218-23.

."Data Set for a Panel of 138 Countries." Data set available on disk from authors, 1997.

Barro, Robert J. and Sala-i-Martin, Xavier. Economic growth. New York: McGraw-Hill, 1995.

Benabou, Roland. "Heterogeneity, Stratification, and Growth: Macroeconomic Implications of Community Structure and School Finance." American Economic Review, June 1996a, 86(3), pp. 584-609.

. "Inequality and Growth," in Ben S.

Bernanke and Julio J. Rotemberg, eds., NBER macroeconomics annual 1996. Cambridge, MA: MIT Press, 1996b, pp. 11-74.

Birdsall, Nancy; Ross, David R. and Sabot, Richard. "Inequality and Growth Reconsidered: Lessons from East Asia." World Bank Economic Review, September 1995, 9(3), pp. 477-508.

Caselli, Francesco; Esquivel, Gerardo and Lefort, Fernando. "Reopening the Convergence Debate: A New Look at Cross-Country Growth Empirics." Journal of Economic Growth, September 1996, 1(3), pp. 363-89. 
Chamberlain, Gary. "Panel Data," in Zvi Griliches and Michael D. Intrilligator, eds., Handbook of econometrics II. Amsterdam: North-Holland, 1984, pp. 1247-318.

Clarke, George R. "More Evidence on Income Distribution and Growth." Journal of Development Economics, August 1995, 47(2), pp. 403-27.

Crépon, Bruno B. and Mairesse, Jacques. "The Chamberlain Approach," in László Mátyás and Patrick Sevestre, eds., The econometrics of panel data. Dordrecht: Kluwer Academic, 1996, pp. 323-96.

Deininger, Klaus and Squire, Lyn. "A New Data Set Measuring Income Inequality." World Bank Economic Review, September 1996, 10(3), pp. 565-91. . "New Ways of Looking at Old Issues: Inequality and Growth." Journal of Development Economics, December 1998, 57(2), pp. 259-87.

Fields, Gary S. "Data for Measuring Poverty and Inequality Changes in the Developing Countries." Journal of Development Economics, June 1994, 44(1), pp. 87-102.

Galor, Oded and Tsiddon, Daniel. "The Distribution of Human Capital and Economic Growth." Journal of Economic Growth, March 1997a, 2(1), pp. 93-124.

. "Technological Progress, Mobility, and Economic Growth." American Economic Review, June 1997b, 87(3), pp. 363-82.

Heston, Alan and Summers, Robert. "The Penn World Tables (Mark 5): An Expanded Set of International Comparisons, 1950-1988." Quarterly Journal of Economics, May 1991, 106(2), pp. 327-68.

Islam, Nazrul. "Growth Empirics: A Panel Data Approach." Quarterly Journal of Economics, November 1995, 110(4), pp. 1127-70.
Judson, Ruth and Owen, Ann L. "Estimating Dynamic Panel Data Models: A Practical Guide for Macroeconomists." Working paper, Federal Reserve Board of Governors, 1996.

$\rightarrow$ Knight, Malcolm D.; Loayza, Norman and Villaneuva, Delano. "Testing the Neoclassical Growth Model." International Monetary Fund Staff Papers, September 1993, 40(3), pp. 51241.

Levine, Ross E. and Renelt, David. "A Sensitivity Analysis of Cross-Country Growth Regressions." American Economic Review, September 1992, 82(4), pp. 942-63.

McGranahan, Donald. International comparability of statistics on income distribution. Geneva: United Nations Research Institute for Social Development, 1979.

Park, Jong-goo and Van Ginneken, Wouter. Generating internationally comparable income distribution estimates. Geneva: International Labour Office, 1984.

Perotti, Roberto. "Growth, Income Distribution and Democracy." Journal of Economic Growth, June 1996, 1(2), pp. 149-87.

Persson, Torsten and Tabellini, Guido. "Is Inequality Harmful for Growth?" American Economic Review, June 1994, 84(3), pp. 600-21.

Saint-Paul, Gilles and Verdier, Thierry. "Education, Democracy, and Growth." Journal of Development Economics, December 1993, 42(2), pp. 399-407.

Verbeek, Marno and Nijman, Theo. "Incomplete Panels and Selection Bias," in László Mátyás and Patrick Sevestre, eds., The econometrics of panel data. Dordrecht: Kluwer Academic, 1996, pp. 449-90.

World Bank. "World*Data 1995." Data set available on CD-ROM, 1995. 